\title{
Spread the Word: International Spillovers from Central Bank Communication
}

\author{
Armelius, Hanna ${ }^{a}$; Bertsch, Christoph ${ }^{\text {b }}$; Hull, Isaiah ${ }^{\text {b }}$ and Zhang, Xin ${ }^{\text {b }}$ \\ ${ }^{\mathrm{a}}$ Ministry of Finance, Sweden; ${ }^{\mathrm{b}}$ Research Division, Sveriges Riksbank
}

\begin{abstract}
We use computational linguistic methods and a novel dataset to measure the sentiment component of central bank communications in 23 countries over the 2002-2016 period. We first construct a Granger causality network to identify how sentiment is transmitted across central banks. The network structure suggests that comovement in sentiment is not reducible to comovement in output across countries. We also show that some central banks in the network, such as the Federal Reserve and the Bundesbank, tend to cause sentiment shifts in other central banks; whereas other central banks, such as the European Central Bank and the Bank of Japan, tend to be shifted by other central banks. Finally, we use a structural VAR to demonstrate that sentiment shocks generate cross-country spillovers in sentiment, policy rates, and real variables.
\end{abstract}

Keywords: Central Bank Communication, Monetary Policy 